\title{
Physicochemical properties and energy content of yellow dent corn from different climatic origins in growing pigs
}

\author{
Wenxuan Dong ${ }^{1}$, Juntao $\mathrm{Li}^{1}$, Zhongchao $\mathrm{Li}^{1}$, Shuo Zhang ${ }^{2}$, Xiaozhen $\mathrm{Li}^{2}$, \\ Chundi Yang ${ }^{2}$, Ling Liu', and Shuai Zhang ${ }^{1, *}$
}

\begin{abstract}
* Corresponding Author: Shuai Zhang Tel: +86-010-62731109, Fax: +86-010-62733688, E-mail: zhangshuai16@cau.edu.cn

${ }^{1}$ State Key Laboratory of Animal Nutrition, China Agricultural University, Beijing 100193, China 2 Yunnan Xiernan Feed Limited Liability Company, Kunming 650216, China
\end{abstract}

\section{ORCID}

Wenxuan Dong

https://orcid.org/0000-0002-0867-8583 Juntao Li

https://orcid.org/0000-0003-2349-9919 Zhongchao Li

https://orcid.org/0000-0002-4488-8756 Shuo Zhang

https://orcid.org/0000-0003-4496-3661 Xiaozhen Li

https://orcid.org/0000-0001-9395-0432 Chundi Yang

https://orcid.org/0000-0003-0486-4917

Ling Liu

https://orcid.org/0000-0002-4704-7143

Shuai Zhang

https://orcid.org/0000-0001-5435-2640

Submitted Sept 10, 2019; Revised Sept 28, 2019; Accepted Nov 25, 2019
Objective: The objective of this study was to determine the digestible energy (DE) and metabolizable energy (ME) of yellow dent corn sourced from different meteorological origins fed to growing pigs and develop equations to predict the DE and ME of yellow dent corn from southwestern China.

Methods: Sixty crossbred barrows were allotted to 20 treatments in a triplicate $20 \times 2$ incomplete Latin square design with 3 replicated pigs per dietary treatment during 2 consecutive periods. Each period lasted for 12 days, and total feces and urine during the last 5 days of each period were collected to calculate the energy contents.

Results: On dry matter (DM) basis, the DE and ME in 20 corn grain samples ranged from 15.38 to $16.78 \mathrm{MJ} / \mathrm{kg}$ and from 14.93 to $16.16 \mathrm{MJ} / \mathrm{kg}$, respectively. Selected best-fit prediction equations for DE and ME (MJ/kg DM basis) for yellow dent corn $(n=16)$ sourced from southwestern China were as follows: $\mathrm{DE}=28.58-(0.12 \times \%$ hemicellulose $)+(0.35 \times \%$ ether extract $)-(0.83 \times \mathrm{MJ} / \mathrm{kg}$ gross energy $)+(0.20 \times \%$ crude protein $)+(0.49 \times \%$ ash $) ; \mathrm{ME}=30.42-$ $(0.11 \times \%$ hemicellulose $)+(0.31 \times \%$ ether extract $)-(0.81 \times \mathrm{MJ} / \mathrm{kg}$ gross energy $)$.

Conclusion: Our results indicated that the chemical compositions, but not the meteorological conditions or physical characteristics could explain the variation of energy contents in yellow dent corn sourced from southwestern China fed to growing pigs.

Keywords: Digestible Energy; Metabolizable Energy; Meteorological Condition; Growing Pigs; Yellow Dent Corn

\section{INTRODUCTION}

Corn is commonly used in commercial swine diets due to its high energy content and low concentrations of anti-nutritional factors compared with other cereal grains [1]. It is widely planted all around the world, with an annual production of over 1 billion tons worldwide [2]. Corns grown under drought-stressed conditions were reported to have greater contents of fibrous components compared with corns harvested under normal conditions [3]. In humid growing and harvest conditions, the nutritional values of corn could be affected by its mold contamination [4] and lower nutrient content [5]. The meteorological conditions under which the corn grows may have influence on the physicochemical properties of corn grains, thus affecting their nutrient properties used as feed ingredients for animals. Corn is one of the major energy sources supplied to pigs, which is directly related to the growth performance and carcass trait in commercial swine production [6]. It is reported that corn grains cultivated from various origins have different energy digestibility, energy retention rate and digestible energy (DE) and metabolizable energy (ME) values [7-10]. However, little information is available on the correlation between nutritional values and 
climatic origins of corn grains fed to growing pigs. Most previous studies focused on some special corn varieties and measured only 1 sample, thus, comprehensive evaluation of the DE and ME contents in yellow dent corn was limited [3-6,8-10].

We hypothesized that yellow dent corn grains grown under different climatic origins have different energy content and digestibility due to the environmental conditions, and that meteorological factors such as temperature, humidity and rainfall may be used as predictors to estimate the energy contents of corn fed to growing pigs. Thus, the objective of this study was to determine the energy contents of yellow dent corn produced from different climatic conditions, explore the relationships between energy contents and meteorological conditions and develop equations to predict the energy contents of yellow dent corns sourced from southwestern China.

\section{MATERIALS AND METHODS}

All protocols used in this experiment were reviewed and approved by the Institutional Animal Care and Use Committee of China Agricultural University (Beijing, China). The animal trials were conducted at the Metabolism Laboratory of the Ministry of Agriculture Feed Industry Center (Chengde, China).

\section{Collection of corn samples}

Sixteen yellow dent corn samples were collected from southwestern China (Yunnan, China) which account for 32\% corn production in China and has diverse climatic conditions. Two yellow dent corn samples were obtained from northeastern China which account for $46 \%$ Chinese corn production and 2 yellow dent corn samples were obtained from Myanmar to provide as much variation as possible. Breeds and fertilization managements of corn samples collected in this study were kept as consistent as possible to eliminate systematic error.

The 20 corn grains were divided into 6 groups based on their geographical origins, including 2 tropical, 2 cold, 4 cool, 4 neutral, 4 warm and 4 hot areas. Detailed information about the origins of the corn samples used in this study is shown in Table 1.

\section{Animals, diets, and experimental design}

The animal trial consisted 2 periods, in each period sixty crossbred growing barrows (Duroc $\times$ Large White $\times$ Landrace, with initial body weight of $29.7 \pm 3.5 \mathrm{~kg}$ for the first period and $34.9 \pm 5.6 \mathrm{~kg}$ for the second period) were allotted to 20 treatment diets in a triplicate $20 \times 2$ incomplete Latin square design with 3 replicated pigs per dietary treatment. Each period lasted for 12 days, including 7 days for experimental diet adaptation and 5 days for total urine and feces collection. Pigs received different experimental diets in each period.

Table 1. Sources and associated climatic conditions of corn grains

\begin{tabular}{|c|c|c|c|c|c|c|c|}
\hline \multirow{2}{*}{ Source } & \multicolumn{3}{|c|}{ Geographic conditions } & \multicolumn{3}{|c|}{ Meteorological conditions ${ }^{1)}$} & \multirow{2}{*}{$\begin{array}{l}\text { Geographical } \\
\text { division }\end{array}$} \\
\hline & Region & Country & Longitude/Latitude & Temperature $\left({ }^{\circ} \mathrm{C}\right)$ & Humidity (\%) & Rainfall (mm) & \\
\hline 1 & - & Myanmar & $\sim 20-22^{\circ} \mathrm{N}, 97-99^{\circ} \mathrm{E}^{2)}$ & - & - & - & Tropical \\
\hline 2 & - & Myanmar & & - & - & - & Tropical \\
\hline 3 & Changchun & China & $43.90^{\circ} \mathrm{N}, 125.32^{\circ} \mathrm{E}$ & 6.1 & 62 & 577.3 & Cold \\
\hline 4 & Jiamusi & China & $46.82^{\circ} \mathrm{N}, 130.37^{\circ} \mathrm{E}$ & 4.0 & 66 & 542.6 & Cold \\
\hline 5 & Xuanwei & China & $26.22^{\circ} \mathrm{N}, 104.10^{\circ} \mathrm{E}$ & 13.7 & 71 & 973.8 & Cool \\
\hline 6 & Huize & China & $26.42^{\circ} \mathrm{N}, 103.30^{\circ} \mathrm{E}$ & 13.0 & 70 & 791.3 & Cool \\
\hline 7 & Zhaotong & China & $27.33^{\circ} \mathrm{N}, 103.72^{\circ} \mathrm{E}$ & 11.8 & 75 & 674.7 & Cool \\
\hline 8 & Dongchuan & China & $26.08^{\circ} \mathrm{N}, 103.18^{\circ} \mathrm{E}$ & 12.8 & 58 & 741.3 & Cool \\
\hline 9 & Yongsheng & China & $26.68^{\circ} \mathrm{N}, 100.75^{\circ} \mathrm{E}$ & 13.7 & 68 & 950.8 & Neutral \\
\hline 10 & Yulong & China & $26.82^{\circ} \mathrm{N}, 100.23^{\circ} \mathrm{E}$ & 12.9 & 62 & 980.2 & Neutral \\
\hline 11 & Deqin & China & $28.48^{\circ} \mathrm{N}, 98.92^{\circ} \mathrm{E}$ & 6.3 & 68 & 650.8 & Neutral \\
\hline 12 & Weixi & China & $27.18^{\circ} \mathrm{N}, 99.28^{\circ} \mathrm{E}$ & 11.8 & 69 & 971.5 & Neutral \\
\hline 13 & Yuxi & China & $24.35^{\circ} \mathrm{N}, 102.55^{\circ} \mathrm{E}$ & 16.3 & 73 & 908.9 & Warm \\
\hline 14 & Qujing & China & $25.50^{\circ} \mathrm{N}, 103.80^{\circ} \mathrm{E}$ & 15.1 & 69 & 944.6 & Warm \\
\hline 15 & Chuxiong & China & $25.03^{\circ} \mathrm{N}, 101.55^{\circ} \mathrm{E}$ & - & - & - & Warm \\
\hline 16 & Dali & China & $25.60^{\circ} \mathrm{N}, 100.23^{\circ} \mathrm{E}$ & 15.1 & 68 & $1,054.8$ & Warm \\
\hline 17 & Wenshan & China & $23.37^{\circ} \mathrm{N}, 104.25^{\circ} \mathrm{E}$ & 18.4 & 75 & 974.7 & Hot \\
\hline 18 & Lincang & China & $23.88^{\circ} \mathrm{N}, 100.08^{\circ} \mathrm{E}$ & 17.8 & 70 & $1,148.9$ & Hot \\
\hline 19 & Puer & China & $23.07^{\circ} \mathrm{N}, 101.03^{\circ} \mathrm{E}$ & - & - & - & Hot \\
\hline 20 & Honghe & China & $23.37^{\circ} \mathrm{N}, 103.40^{\circ} \mathrm{E}$ & 20.6 & 74 & 832.2 & Hot \\
\hline
\end{tabular}

1) All data were retrieved from http://data.cma.cn/ (Access time: Oct. 1, 2018; time period of observation: from 2008 to 2018).

${ }^{2)}$ Approximate longitude and latitude of the major corn production area in Myanmar. 
In addition, 7 days for metabolism crates adaptation and 5 days for diet transition using a fully balanced growing diet between each period were also included in the whole animal trial. All pigs were individually housed in stainless-steel metabolism crates $(1.4 \times 0.7 \times 0.6 \mathrm{~m})$ that were equipped with a nipple drinker and a feeder and placed in a temperaturecontrolled room with the temperature maintained at $22^{\circ} \mathrm{C}$ $\pm 2^{\circ} \mathrm{C}$. Daily feed allowance, equivalent to $4 \%$ of the body weight determined at the beginning of each period, was divided into 2 equal-sized meals provided at 0830 and 1530 hours, respectively. Water was provided ad libitum via the nipple drinker. The feed refusals and spillages were collected twice daily, dried, and weighed during the 5 days of urine and feces collection period.

The 20 treatment diets were formulated to contain $96.9 \%$ of one of the 20 corn samples as the only energy source (Table 2 ). The amount of vitamin and mineral premix was kept consistent in all diets and adjusted to meet the nutrient requirements of growing pigs recommended by NRC [11].

\section{Sample collection}

Fecal samples were collected using plastic bags (one bag per pig) as soon as they appeared in the metabolism crates and stored at $-20^{\circ} \mathrm{C}$ immediately. At the end of the collection period, the total 5 days fecal productions from each pig were blended and weighed. Approximately $300 \mathrm{~g}$ sub-samples of feces were weighed and dried in a forced-air drying oven at $65^{\circ} \mathrm{C}$ for 72 hours after thawing and mixing thoroughly. Subsamples were stored at $-20^{\circ} \mathrm{C}$ for further analysis after drying. Total urine was collected into plastic buckets (one bucket per pig) containing $50 \mathrm{~mL}$ of $6 \mathrm{~mol} / \mathrm{L}$ hydrochloric acid $(\mathrm{HCl})$ and placed under the metabolism crates. The $\mathrm{HCl}$ was added to reduce the nitrogen loss and limit the proliferation of bacteria. The volume of collected urine was measured every day and $10 \%$ of the daily urinary collection was stored at $-20^{\circ} \mathrm{C}$. Urine samples were pooled for each pig after the collection period. Approximately $45 \mathrm{~mL}$ sub-samples were collected for

Table 2. Ingredient compositions of the experimental diets (\% as-fed basis)

\begin{tabular}{lc}
\hline Ingredient & Levels \\
\hline Corn & 96.90 \\
Dicalcium phosphate & 1.70 \\
Limestone & 0.60 \\
Salt & 0.30 \\
Vitamin and mineral premix ${ }^{1)}$ & 0.50 \\
\hline
\end{tabular}

\footnotetext{
1) Premix provided the following quantities per kilogram of complete diet: vitamin A as retinyl acetate, 5,512 IU; vitamin $D_{3}$ as cholecalciferol, 2,200 IU; vitamin E as DL-alpha-tocopheryl acetate, $30 \mathrm{IU}$; vitamin $\mathrm{K}_{3}$ as menadione nicotinamide bisulfite, 2.2 mg; vitamin $B_{12}, 27.6 \mu$; riboflavin, 4 mg; pantothenic acid as DL-calcium pantothenate, $14 \mathrm{mg}$; niacin, $30 \mathrm{mg}$; choline chloride, $400 \mathrm{mg}$; folacin, $0.7 \mathrm{mg}$; thiamin as thiamine mononitrate, $1.5 \mathrm{mg}$; pyridoxine as pyridoxine hydrochloride, $3 \mathrm{mg}$; biotin, $44 \mu \mathrm{g} ; \mathrm{Mn}$ as $\mathrm{MnO}, 40 \mathrm{mg}$; Fe as $\mathrm{FeSO}_{4} \cdot \mathrm{H}_{2} \mathrm{O}, 75 \mathrm{mg}$; Zn as $\mathrm{ZnO}, 75$ mg; Cu as CuSO ${ }_{4} \cdot 5 \mathrm{H}_{2} \mathrm{O}, 100 \mathrm{mg}$; I as Kl, $0.3 \mathrm{mg}$; $\mathrm{Se}$ as $\mathrm{Na}_{2} \mathrm{SeO}_{3}, 0.3 \mathrm{mg}$.
}

further chemical analysis. The fecal and feed samples were ground to pass through 40 mesh screens prior to proximate analysis and 60 mesh screens for AA analysis.

\section{Chemical analysis}

Dry matter (DM; method 930.15), ash (method 942.15), crude protein (CP; method 990.03), ether extract (EE; method 920.39), crude fiber (CF; method 978.10), calcium (Ca; method 978.02) and phosphorus (P; method 946.06) of all corn samples were determined according to AOAC [12]. Filter bags (Model F57; Ankom Technology, Macedon, NY, USA) and fiber analyzer equipment (ANKOM200 Fiber Analyzer, Ankom Technology, USA) were used to determine the neutral detergent fiber (NDF) and acid detergent fiber (ADF) contents of the corn samples [13]. Hemicellulose was calculated as the difference between NDF and ADF concentrations. Total starch of all corn samples was analyzed using a commercial Starch Assay Kit (STA20; Sigma-Aldrich Corporation, St. Louis, MO, USA) according to method 7613.01 of the AOAC [12]. All corn samples were analyzed for AA according to the standard method described by AOAC [12]. Fifteen AAs were determined after hydrolysis with $6 \mathrm{~mol} / \mathrm{L} \mathrm{HCl}$ at $110^{\circ} \mathrm{C}$ for 24 hours using an AA Analyzer. Methionine and cysteine were determined as methionine sulphone and cysteic acid using an AA analyzer after cold performic acid oxidation overnight and hydrolyzing with $7.5 \mathrm{~mol} / \mathrm{L} \mathrm{HCl}$ at $110^{\circ} \mathrm{C}$ for 24 hours. Tryptophan was determined using high performance liquid chromatography (Agilent 1,200 Series, Santa Clara, CA, USA) after $\mathrm{LiOH}$ hydrolysis for 22 hours at $110^{\circ} \mathrm{C}$. The corn grains were analyzed for bulk weight and 1,000 kernel weight according to Li et al [8]. The gross energy (GE) of feces, urine, diets, and corn samples were analyzed using an automatic isoperibol oxygen bomb calorimeter (model 6400; Parr1281 Calorimeter, Moline, IL, USA) calibrated by benzoic acid $(26.45 \mathrm{MJ} / \mathrm{kg})$. All analysis was conducted in duplicate.

\section{Calculations}

The DE and ME contents of diets and corn grains as well as the apparent total tract digestibility (ATTD) of GE were calculated using the equations described by Adeola [14] as follows:

$$
\begin{aligned}
& \operatorname{DEd}(\mathrm{MJ} / \mathrm{kg})=(\mathrm{GEi}-\mathrm{GEf}) / \mathrm{DMi} ; \\
& \operatorname{DEc}(\mathrm{MJ} / \mathrm{kg})=\mathrm{DEd} / 0.969 ; \\
& \operatorname{MEd}(\mathrm{MJ} / \mathrm{kg})=(\mathrm{GEi}-\mathrm{GEf}-\mathrm{GEu}) / \mathrm{DMi} ; \\
& \operatorname{MEc}(\mathrm{MJ} / \mathrm{kg})=\operatorname{MEd} / 0.969 ; \\
& \text { ATTD of GE }(\%)=(\mathrm{GEi}-\mathrm{GEf}) / \mathrm{GEi},
\end{aligned}
$$


where DEd and MEd represent the DE and ME contents in each diet, respectively; GEi (MJ), GEf (MJ), and GEu (MJ) represent the total GE intake, GE output in feces, and GE output in urine, respectively; DMi represents dry matter intake (DMi); DEc and MEc represent the DE and ME contents in corn grains, respectively; 0.969 is the percentage of corn grains included in diets.

The net energy (NE) content of corn grains were calculated using the equation: $\mathrm{NE}(\mathrm{MJ} / \mathrm{kg} \mathrm{DM})=([0.73 \times \mathrm{ME}]+[1.33$ $\times \mathrm{EE}]+[0.39 \times$ starch $]-[0.62 \times \mathrm{CP}]-[0.83 \times \mathrm{ADF}]) \times 0.0041868$, in which chemical components are expressed as $\mathrm{g} / \mathrm{kg} \mathrm{DM}[15]$.

\section{Statistical analysis}

Data were checked for normality using the UNIVARIATE procedure of SAS 9.2 (SAS Inst. Inc., Carry, NC, USA). No outliers were identified. Then data were analyzed using the PROC MIXED procedure of SAS. Dietary treatment was the only fixed effect and period was the random effect included in the model and the individual pig was treated as the experimental unit. There was no interaction between treatment and period. The LSMEANS statement was used to calculate the least squares means for each treatment with Tukey's adjustment. The correlation coefficients ( $\mathrm{r}$ ) among the chemical compositions and energy values were calculated using the

Table 3. Variability of nutrient compositions among 20 corn grain samples with different climatic origins

\begin{tabular}{|c|c|c|c|c|c|c|c|c|c|c|c|}
\hline \multirow{2}{*}{ Items } & \multirow{2}{*}{ Mean } & \multirow{2}{*}{ Min } & \multirow{2}{*}{ Max } & \multirow{2}{*}{ SD } & \multirow{2}{*}{ CV } & \multicolumn{6}{|c|}{ Means of geographical divisions ${ }^{1)}$} \\
\hline & & & & & & Tropical & Cold & Cool & Neutral & Warm & Hot \\
\hline DM & 88.21 & 86.78 & 89.65 & 0.62 & 0.71 & 87.68 & 88.93 & 87.88 & 88.33 & 88.44 & 87.98 \\
\hline GE (MJ/kg DM) & 18.40 & 18.09 & 18.68 & 0.13 & 0.73 & 18.48 & 18.29 & 18.52 & 18.36 & 18.32 & 18.41 \\
\hline \multicolumn{12}{|c|}{ Chemical composition (\% DM) } \\
\hline $\mathrm{CP}$ & 9.32 & 8.34 & 10.28 & 0.52 & 5.55 & 9.32 & 8.79 & 9.08 & 9.72 & 9.58 & 9.15 \\
\hline $\mathrm{EE}$ & 4.05 & 2.81 & 4.98 & 0.56 & 14.01 & 4.48 & 3.89 & 4.16 & 4.63 & 3.52 & 3.76 \\
\hline CF & 3.31 & 2.67 & 3.71 & 0.26 & 7.87 & 3.49 & 2.85 & 3.46 & 3.33 & 3.40 & 3.17 \\
\hline Ash & 1.38 & 1.09 & 1.96 & 0.18 & 13.04 & 1.49 & 1.69 & 1.28 & 1.45 & 1.27 & 1.34 \\
\hline NDF & 13.01 & 10.18 & 14.86 & 1.30 & 10.01 & 13.40 & 11.21 & 13.66 & 12.34 & 13.16 & 13.57 \\
\hline$A D F$ & 3.70 & 2.04 & 4.58 & 0.46 & 12.55 & 3.85 & 2.84 & 3.81 & 3.83 & 3.95 & 3.58 \\
\hline $\mathrm{HC}$ & 9.30 & 10.75 & 7.20 & 1.08 & 11.65 & 9.55 & 8.37 & 9.37 & 8.51 & 9.21 & 9.99 \\
\hline Starch & 79.65 & 75.09 & 82.65 & 1.93 & 2.42 & 76.29 & 80.30 & 80.32 & 78.41 & 80.77 & 80.46 \\
\hline $\mathrm{Ca}$ & 0.02 & 0.01 & 0.03 & $<0.01$ & 35.78 & 0.02 & 0.01 & 0.01 & 0.02 & 0.02 & 0.02 \\
\hline$P$ & 0.27 & 0.20 & 0.33 & 0.03 & 13.77 & 0.31 & 0.30 & 0.27 & 0.26 & 0.28 & 0.23 \\
\hline \multicolumn{12}{|c|}{ Physical characteristic, as-fed basis } \\
\hline Bulk weight (g/L) & 757.2 & 706.5 & 799.5 & 23.43 & 3.10 & 798.0 & 721.5 & 745.1 & 753.9 & 763.1 & 757.8 \\
\hline TKW (g) & 326.0 & 265.0 & 377.5 & 29.94 & 9.18 & 265.0 & 307.5 & 342.5 & 338.1 & 313.8 & 337.5 \\
\hline \multicolumn{12}{|c|}{ Indispensable amino acid (\% DM) } \\
\hline Arginine & 0.40 & 0.24 & 0.51 & 0.07 & 16.38 & 0.35 & 0.38 & 0.46 & 0.44 & 0.41 & 0.35 \\
\hline Histidine & 0.28 & 0.23 & 0.38 & 0.04 & 14.47 & 0.29 & 0.24 & 0.27 & 0.29 & 0.26 & 0.33 \\
\hline Isoleucine & 0.33 & 0.28 & 0.41 & 0.03 & 9.07 & 0.32 & 0.30 & 0.32 & 0.36 & 0.33 & 0.31 \\
\hline Leucine & 1.12 & 0.93 & 1.45 & 0.12 & 11.07 & 1.11 & 1.02 & 1.12 & 1.25 & 1.12 & 1.03 \\
\hline Lysine & 0.29 & 0.25 & 0.37 & 0.03 & 9.79 & 0.29 & 0.27 & 0.27 & 0.33 & 0.29 & 0.31 \\
\hline Methionine & 0.20 & 0.16 & 0.25 & 0.02 & 11.21 & 0.21 & 0.18 & 0.20 & 0.19 & 0.21 & 0.21 \\
\hline Phenylalanine & 0.43 & 0.36 & 0.56 & 0.04 & 9.30 & 0.42 & 0.38 & 0.44 & 0.47 & 0.44 & 0.41 \\
\hline Threoine & 0.33 & 0.28 & 0.42 & 0.03 & 8.85 & 0.33 & 0.30 & 0.33 & 0.37 & 0.33 & 0.32 \\
\hline Tryptophan & 0.07 & 0.06 & 0.10 & 0.01 & 16.35 & 0.06 & 0.07 & 0.08 & 0.07 & 0.07 & 0.07 \\
\hline Valine & 0.44 & 0.37 & 0.52 & 0.03 & 7.23 & 0.44 & 0.40 & 0.44 & 0.48 & 0.44 & 0.43 \\
\hline \multicolumn{12}{|c|}{ Dispensable amino acid (\% DM) } \\
\hline Alanine & 0.56 & 0.48 & 0.71 & 0.05 & 9.12 & 0.55 & 0.52 & 0.55 & 0.62 & 0.56 & 0.53 \\
\hline Aspartic acid & 0.57 & 0.52 & 0.69 & 0.04 & 7.06 & 0.55 & 0.56 & 0.56 & 0.61 & 0.57 & 0.55 \\
\hline Cysteine & 0.20 & 0.16 & 0.24 & 0.02 & 9.47 & 0.19 & 0.17 & 0.20 & 0.20 & 0.21 & 0.22 \\
\hline Glutamic acid & 1.52 & 1.28 & 1.93 & 0.15 & 9.68 & 1.51 & 1.40 & 1.53 & 1.67 & 1.53 & 1.43 \\
\hline Glycine & 0.29 & 0.24 & 0.32 & 0.02 & 6.52 & 0.29 & 0.25 & 0.29 & 0.29 & 0.29 & 0.30 \\
\hline Proline & 0.93 & 0.79 & 1.07 & 0.07 & 7.65 & 0.96 & 0.85 & 0.93 & 0.97 & 0.91 & 0.97 \\
\hline Serine & 0.40 & 0.34 & 0.50 & 0.04 & 10.19 & 0.40 & 0.37 & 0.39 & 0.44 & 0.40 & 0.38 \\
\hline Tyrosine & 0.31 & 0.22 & 0.40 & 0.05 & 15.70 & 0.28 & 0.24 & 0.30 & 0.37 & 0.28 & 0.33 \\
\hline
\end{tabular}

Min, minimum; Max, maximum; SD, standard deviation; $C V$, coefficient of variation; $D M$, dry matter; $G E$, digestible energy; $C P$, crude protein; $E E$, ether extract; $C F$, crude fiber; NDF, neutral detergent fiber; ADF, acid detergent fiber; HC, hemicellulose; Ca, Calcium; P, Phosphorus; TKW, thousand kernel weight.

1) Sources of corn grains are described according to its geographical divisions. 
CORR procedure of SAS 9.2. Prediction equations for the $\mathrm{DE}$ and ME contents of corn grains were developed using the REG procedure of SAS 9.2. Stepwise regression was used with chemical compositions as independent variables. The $\mathrm{R}^{2}$, $\mathrm{p}$-value, the Mallows statistic $(\mathrm{C}(\mathrm{p}))$, Bayesian information criterion (BIC), root mean square error (RMSE) and Akaike's information criterion (AIC) were used to identify the best-fit equations. In all analyses, the differences were considered significant if $\mathrm{p}<0.05$.

\section{RESULTS}

\section{Nutrient composition}

Variability of nutrient compositions among the 20 corn grains and among different geographical regions are shown in Table 3. On DM basis, the average $\mathrm{CP}, \mathrm{EE}, \mathrm{CF}$, ash, $\mathrm{NDF}, \mathrm{ADF}$, starch, $\mathrm{Ca}$, and $\mathrm{P}$ concentrations of 20 corn samples were $9.32 \%$, $4.05 \%, 3.31 \%, 1.38 \%, 13.01 \%, 3.70 \%, 79.65 \%, 0.02 \%$, and $0.27 \%$, respectively. The average bulk weight and 1,000 kernel weight of corn grains were $757.2 \mathrm{~g} / \mathrm{L}$ and $326.0 \mathrm{~g}$ on as-fed basis, respectively.

\section{Energy contents}

The ATTD of GE in 20 corn grain samples ranged from $85.54 \%$ to $89.96 \%$ with a mean value of $87.65 \%$ (Table 4 ). On DM basis, the DE, ME and NE contents of the 20 corn

Table 4. Energy contents in the 20 corn grain samples with different climatic origins (dry matter basis)

\begin{tabular}{|c|c|c|c|c|c|c|}
\hline Sources" & $\mathrm{DE}(\mathrm{MJ} / \mathrm{kg})$ & ME (MJ/kg) & $\mathrm{NE}(\mathrm{MJ} / \mathrm{kg})$ & NE/ME & ME/DE & ATTD of GE (\%) \\
\hline \multicolumn{7}{|l|}{ Tropical } \\
\hline 1 & $16.26^{\mathrm{ab}}$ & 15.65 & 12.62 & 0.81 & 0.98 & 87.06 \\
\hline 2 & $16.03^{\mathrm{ab}}$ & 15.67 & 12.73 & 0.81 & 0.97 & 87.67 \\
\hline Mean & $16.30^{x y}$ & $15.84^{x y}$ & $12.76^{x y}$ & 0.81 & 0.97 & $87.75^{x y}$ \\
\hline \multicolumn{7}{|l|}{ Cold } \\
\hline 3 & $16.35^{\mathrm{ab}}$ & 15.73 & 12.85 & 0.80 & 0.98 & 88.51 \\
\hline 4 & $16.24^{a b}$ & 15.77 & 12.99 & 0.81 & 0.98 & 88.91 \\
\hline Mean & $16.23^{x y}$ & $15.81^{x y}$ & $12.80^{x y}$ & 0.81 & 0.98 & $88.65^{x}$ \\
\hline \multicolumn{7}{|l|}{ Cool } \\
\hline 5 & $16.49^{\mathrm{ab}}$ & 15.91 & 12.74 & 0.80 & 0.97 & 88.43 \\
\hline 6 & $15.38^{b}$ & 14.93 & 12.82 & 0.81 & 0.98 & 85.73 \\
\hline 7 & $16.02^{a b}$ & 15.72 & 13.03 & 0.81 & 0.98 & 86.81 \\
\hline 8 & $15.87^{\mathrm{ab}}$ & 15.52 & 12.53 & 0.81 & 0.97 & 86.82 \\
\hline Mean & $15.93^{y}$ & $15.47^{y}$ & $12.54^{y}$ & 0.81 & 0.97 & $86.77^{y}$ \\
\hline \multicolumn{7}{|l|}{ Neutral } \\
\hline 9 & $16.68^{\mathrm{ab}}$ & 16.01 & 12.16 & 0.81 & 0.97 & 88.99 \\
\hline 10 & $16.78^{\mathrm{a}}$ & 16.14 & 12.64 & 0.80 & 0.98 & 89.96 \\
\hline 11 & $16.30^{\mathrm{ab}}$ & 16.16 & 12.68 & 0.81 & 0.98 & 88.53 \\
\hline 12 & $16.30^{\mathrm{ab}}$ & 15.97 & 12.63 & 0.81 & 0.98 & 88.04 \\
\hline Mean & $16.41^{x}$ & $15.97^{\mathrm{x}}$ & $12.88^{x}$ & 0.81 & 0.98 & $88.75^{x}$ \\
\hline \multicolumn{7}{|l|}{ Warm } \\
\hline 13 & $16.49^{\mathrm{ab}}$ & 15.90 & 13.09 & 0.81 & 0.97 & 88.43 \\
\hline 14 & $15.88^{\mathrm{ab}}$ & 15.66 & 12.88 & 0.81 & 0.98 & 87.25 \\
\hline 15 & $15.94^{\mathrm{ab}}$ & 15.60 & 12.72 & 0.81 & 0.98 & 87.47 \\
\hline 16 & $16.13^{\mathrm{ab}}$ & 15.44 & 12.85 & 0.81 & 0.97 & 87.48 \\
\hline Mean & $16.12^{x y}$ & $15.67^{x y}$ & $12.63^{x y}$ & 0.81 & 0.97 & $87.72^{x y}$ \\
\hline \multicolumn{7}{|l|}{ Hot } \\
\hline 17 & $15.80^{\mathrm{ab}}$ & 15.46 & 12.62 & 0.81 & 0.98 & 86.82 \\
\hline 18 & $16.23^{\mathrm{ab}}$ & 15.89 & 12.66 & 0.81 & 0.98 & 87.28 \\
\hline 19 & $15.98^{\mathrm{ab}}$ & 15.63 & 12.35 & 0.81 & 0.97 & 87.25 \\
\hline 20 & $16.13^{\mathrm{ab}}$ & 15.33 & 12.49 & 0.81 & 0.97 & 85.54 \\
\hline Mean & $15.99^{x y}$ & $15.62^{x y}$ & $12.63^{x y}$ & 0.81 & 0.98 & $86.89^{y}$ \\
\hline SEM & 0.02 & 0.03 & 0.02 & $<0.01$ & $<0.01$ & 0.28 \\
\hline p (source) & 0.017 & 0.146 & 0.102 & 0.317 & 0.676 & 0.128 \\
\hline $\mathrm{p}$ (division) & 0.011 & 0.032 & 0.049 & 0.518 & 0.394 & 0.002 \\
\hline
\end{tabular}

$\mathrm{DE}$, digestible energy; ME, metabolizable energy; NE, net energy; ATTD, apparent total tract digestibility; GE, gross energy; SEM, standard error of the mean.

1) Sources of corn grains are described according to its geographical divisions.

$a, b$ Means among 20 corn grain sources differ without a common superscript $(p<0.05)$.

${ }^{x, y}$ Means among 6 geographical divisions differ without a common superscript $(p<0.05)$. 
grain samples averaged 16.16, 15.70, and $12.70 \mathrm{MJ} / \mathrm{kg}$, respectively. The NE/ME and ME/DE ratios were consistent among corn grains and ranged from 0.80 to 0.81 and 0.97 to 0.98 , respectively. In terms of corn sources, significantly greater $(\mathrm{p}<0.05)$ DE content was observed in source 10 compared with source 6 . However, in terms of harvest regions, corn grains grown in the neutral area had greater $(\mathrm{p}<0.05)$ $\mathrm{DE}, \mathrm{ME}$, and NE contents than those grown in the area.

\section{Correlation coefficients and prediction equations}

Correlation coefficients between chemical characteristics, physical characteristics, climatic coefficients, and energy content of corn grains are shown in Table 5. Positive correlation was detected between DE and ME contents ( $\mathrm{p}<0.01$, $\mathrm{r}=0.86$ ). In addition, $\mathrm{EE}$ was positively correlated with $\mathrm{DE}$ and ME contents ( $\mathrm{p}<0.05, \mathrm{r}=0.56$ and 0.46 , respectively). The NDF showed negative correlation with DE and ME contents ( $\mathrm{p}<0.05, \mathrm{r}=-0.60$, and -0.56 , respectively). Hemicellulose was negatively correlated with DE and ME contents $(\mathrm{p}<0.01$, $r=-0.68$ and -0.69 , respectively). The GE also showed negative correlation with $\mathrm{DE}$ content $(\mathrm{p}<0.05, \mathrm{r}=-0.46)$. Moreover, the environmental temperature of the cropping condition demonstrated negative correlation with the ash content in corn grains $(\mathrm{p}<0.05, \mathrm{r}=-0.48)$. Otherwise, no significant correlation was observed between physicochemical or climatic conditions and energy contents in corn grains. The ATTD of GE was positively correlated with ME, DE, and ash content $(\mathrm{p}<0.05 ; \mathrm{r}=0.83,0.90$, and 0.49 , respectively), but negatively correlated with the NDF and hemicellulose concentrations $(\mathrm{p}<0.01, \mathrm{r}=-0.71$, and $\mathrm{r}=-0.78$, respectively).

The equations developed to predict the DE and ME contents and ATTD of GE in corn $(n=16)$ sourced from southwestern China are presented Table 6 . The prediction equations with greater R2 and smaller RMSE, AIC, and BIC values were selected. The best-fit equations for DE, ME (MJ/kg DM), and ATTD of GE (\%) in 20 corn samples evaluated in current study were: $\mathrm{DE}=28.58-(0.12 \times$ hemicellulose $)+(0.35 \times \mathrm{EE})-$ $(0.83 \times$ gross energy $)+(0.20 \times \mathrm{CP})+(0.49 \times \mathrm{ash}), \mathrm{ME}=30.42-$ $(0.11 \times$ hemicellulose $)+(0.31 \times \mathrm{EE})-(0.81 \times$ gross energy $)$, and ATTD of GE $(\%)=122.83-(0.54 \times$ hemicellulose $)+(0.66 \times \mathrm{EE})$ $+(1.89 \times$ ash $)-(1.92 \times$ gross energy $)$, in which chemical components were expressed in \% DM and GE were expressed as $\mathrm{MJ} / \mathrm{kg} \mathrm{DM}$.

\section{DISCUSSION}

\section{Nutrient composition}

The physical property, chemical analysis, and AA concentrations in 20 corn grains observed in this study were within the range of values reported by previous studies [1,11,16-18].

In terms of physical characteristics, 1,000 kernel weight (coefficient of variance; $\mathrm{CV}=9.18 \%$ ) was more variable compared with bulk weight $(\mathrm{CV}=3.10 \%)$, which agrees with the results reported by Li et al [9] and Newman et al [3]. Corn grain samples (i.e. sources 1 and 2) from Myanmar (tropical) had greater bulk weight and lower 1,000 kernel weight compared to corn grain samples obtained from China. Extreme temperatures or rainfall during the developmental stage of corn cobs can reduce the production and decrease the quality of the kernel [19-21]. However, we failed to draw a conclusion that physical characteristics of corn grains were affected by the cropping temperature or rainfall in the current study due to the lack of Burmese meteorological conditions. Similar re-

Table 5. Correlation coefficients among chemical characteristics, physical characteristics, climatic conditions and energy contents of 20 corn grain samples

\begin{tabular}{|c|c|c|c|c|c|c|c|c|c|c|c|c|c|c|c|c|}
\hline Item & ME & $\mathrm{DE}$ & GE & Ash & $\mathrm{CP}$ & $\mathrm{EE}$ & NDF & ADF & $\mathrm{HC}$ & $\mathrm{CF}$ & Starch & BWT & TKW & Tem & Hum & Rainfall \\
\hline$D E$ & 0.86 ** & - & - & - & - & - & - & - & - & - & - & - & - & - & - & - \\
\hline $\mathrm{GE}$ & -0.41 & $-0.46^{*}$ & - & - & - & - & - & - & - & - & - & - & - & - & - & - \\
\hline Ash & 0.44 & 0.40 & -0.10 & - & - & - & - & - & - & - & - & - & - & - & - & - \\
\hline$C P$ & 0.19 & 0.26 & -0.11 & -0.13 & - & - & - & - & - & - & - & - & - & - & - & - \\
\hline EE & $0.56^{*}$ & $0.46^{*}$ & 0.25 & 0.33 & -0.12 & - & - & - & - & - & - & - & - & - & - & - \\
\hline NDF & $-0.56^{*}$ & $-0.60^{* *}$ & $0.45^{*}$ & -0.17 & -0.05 & -0.10 & - & - & - & - & - & - & - & - & - & - \\
\hline$A D F$ & -0.10 & -0.19 & 0.32 & -0.11 & 0.18 & -0.02 & 0.61 ** & - & - & - & - & - & - & - & - & - \\
\hline $\mathrm{HC}$ & $-0.69^{* *}$ & $-0.68^{* *}$ & 0.47 & -0.13 & -0.08 & -0.09 & 0.94 & 0.34 & - & - & - & - & - & - & - & - \\
\hline$C F$ & -0.22 & -0.18 & $0.55^{*}$ & -0.21 & 0.31 & 0.20 & 0.44 & 0.58 ** & 0.35 & - & - & - & - & - & - & - \\
\hline Starch & -0.35 & -0.43 & -0.06 & -0.25 & -0.17 & -0.48 * & 0.18 & 0.02 & 0.16 & -0.24 & - & - & - & - & - & - \\
\hline BWT & -0.14 & -0.10 & 0.40 & -0.39 & 0.11 & 0.09 & 0.10 & 0.21 & 0.12 & 0.34 & $-0.46^{*}$ & - & - & - & - & - \\
\hline TKW & -0.26 & -0.25 & 0.38 & -0.33 & 0.11 & 0.06 & 0.35 & 0.07 & 0.33 & 0.20 & 0.27 & -0.29 & - & - & - & - \\
\hline Tem & -0.20 & -0.25 & -0.04 & -0.48 * & 0.31 & -0.31 & 0.35 & 0.26 & 0.31 & 0.16 & 0.45 & -0.01 & 0.39 & - & - & - \\
\hline Hum & 0.16 & 0.06 & -0.02 & -0.12 & -0.03 & -0.17 & -0.31 & 0.01 & -0.38 & -0.38 & 0.19 & -0.13 & 0.25 & 0.04 & - & - \\
\hline Rainfall & 0.25 & 0.17 & -0.04 & -0.23 & -0.18 & -0.02 & -0.18 & 0.14 & -0.27 & -0.31 & 0.08 & 0.01 & 0.36 & 0.26 & 0.90 ** & - \\
\hline ATTD of GE & $0.83^{* *}$ & $0.90^{* *}$ & -0.48 & $0.49^{*}$ & 0.26 & 0.35 & -0.71 ** & -0.17 & $-0.78^{* *}$ & -0.30 & -0.26 & -0.32 & -0.22 & -0.31 & -0.37 & 0.20 \\
\hline
\end{tabular}

ME, metabolizable energy; DE, digestible energy; GE, gross energy; CP, crude protein; EE, ether extract; NDF, neutral detergent fiber; ADF, acid detergent fiber; HC, hemicellulose; CF, crude fiber; BWT, bulk weight; TKW, thousand kernel weight; Tem, temperature; Hum, humidity; ATTD, apparent total tract digestibility.

${ }^{*} p<0.05 ;{ }^{* *} p<0.01$. 
Table 6. Prediction equations for digestible energy, metabolizable energy, and apparent total tract digestibility of gross energy in 20 corn grain samples with different climatic origins using stepwise regression (dry matter basis)

\begin{tabular}{|c|c|c|c|c|c|c|c|}
\hline \multirow{2}{*}{ Item } & \multirow{2}{*}{ Regression equations ${ }^{1)}$} & \multicolumn{6}{|c|}{ Statistics } \\
\hline & & $\mathbf{R}^{2}$ & $C(p)$ & RMSE & AIC & BIC & p-value \\
\hline \multicolumn{8}{|c|}{ Prediction equations for DE (MJ/kg) } \\
\hline 2 & $\mathrm{DE}=28.58-(0.12 \times \mathrm{HC})+(0.35 \times \mathrm{EE})-(0.83 \times \mathrm{GE})+(0.20 \times \mathrm{CP})+(0.49 \times$ ash $)$ & 0.88 & 2.65 & 0.14 & -60.85 & -52.90 & $<0.01$ \\
\hline \multicolumn{8}{|c|}{ Prediction equations for ME (MJ/kg) } \\
\hline 3 & $\mathrm{ME}=32.52-(0.07 \times \mathrm{NDF})+(0.33 \times \mathrm{EE})-(0.94 \times \mathrm{GE})$ & 0.70 & 8.91 & 0.17 & -66.53 & -64.88 & $<0.01$ \\
\hline \multicolumn{8}{|c|}{ Prediction equations for ATTD of GE (\%) } \\
\hline 5 & ATTD of $\mathrm{GE}=132.12-(0.53 \times \mathrm{NDF})+(0.83 \times \mathrm{EE})+(1.81 \times \mathrm{ash})+(0.88 \times \mathrm{ADF})-(2.54 \times \mathrm{GE})$ & 0.85 & 8.21 & 0.49 & -23.89 & -19.19 & $<0.01$ \\
\hline 6 & ATTD of GE $=122.83-(0.54 \times \mathrm{HC})+(0.66 \times \mathrm{EE})+(1.89 \times$ ash $)-(1.92 \times \mathrm{GE})$ & 0.86 & 5.65 & 0.45 & -22.74 & -14.79 & $<0.01$ \\
\hline
\end{tabular}

$\mathrm{DE}$, digestible energy; ME, metabolizable energy; ATTD, apparent total tract digestibility; GE, gross energy; C(p), the Mallows statistics; RMSE, root mean square error; AIC, Akaike's information criterion; BIC, Bayesian information criterion; NDF, neutral detergent fiber; EE, ether extract; CP, crude protein; HC, hemicellulose; ADF, acid detergent fiber.

1) Values were determined with 6 observations per sample; chemical components were expressed as \% dry matter; gross energy were expressed as MJ/kg dry matter.

sults were also observed by Newman et al [3] that bulk weight and 1,000 kernel weight of corn grains were virtually identical between drought-stressed year and normal years.

The mean NDF and ADF contents observed in this study were greater than the values reported by NRC $(10.3 \%$ and $3.3 \%$, respectively), Sauvant et al $(12.0 \%$ and $3.0 \%$, respectively) and CVB (11.6\% and 3.2\%, respectively) [11,16,17]. But Bertol et al [22] reported that NDF concentrations of 2 lots was $15.09 \%$ and $13.57 \%$, which were similar to the values observed in the current experiment, indicating that the nutrition compositions of corn grains grown nowadays may be different from those in the previous feedstuff tables. Newman et al [3] reported significantly lower ADF and NDF concentrations in drought-stressed corn grain compared with crops grown in normal conditions. However, Wang and Zhang [23] and Guo et al [24] concluded that there was no relationship between chemical compositions of corn and the meteorological factors. One possible explanation for these discrepancies may be the extreme weather conditions that have appeared in recent years all around the world, which may influence the development of corn cobs. As for the major energy-yielding composition, starch content of corn grains used in this study were also greater than the values in previous feedstuff tables. For example, the mean starch concentrations reported in NRC [11] and Sauvant et al [16] were 70.8\% and 74.2\% for yellow dent corn, respectively, and was $76.7 \%$ for NutriDense corn in NRC [11]. Otherwise, the values of other chemical constituents such as $\mathrm{CP}, \mathrm{EE}, \mathrm{CF}, \mathrm{Ash}, \mathrm{Ca}$, and $\mathrm{P}$ were similar in our study compared with the previous reported values $[11,16,17]$. The development of corn breeding may also explain the change of starch and fiber contents in corn grown nowadays. The AA concentrations in corn samples used in the current study were similar to those values reported in previous studies $[11,16,25,26]$. For example, the average lysine content of corn samples used in the current study was $0.29 \%$, which was consistent with the value of $0.28 \%$ in NRC [11] and Sauvant et al [16], and the CV of AA concentrations ranging from $6.52 \%$ to $16.35 \%$ were relatively low. Further exploration about the influence of meteorological conditions on AA concentrations in corn was not conducted due to the relatively consistent AA concentrations.

\section{Energy contents}

No significant differences were observed in ATTD of GE among 20 different corn sources. However, in terms of harvest region, the ATTD of GE in corn grains harvested from neutral area were significantly greater than those from cool area. Park et al [10] evaluated the ATTD of GE in 9 corn grain sources and reported a range from $84.0 \%$ to $87.7 \%$. Newman et al [3] demonstrated that the ATTD of GE in 28 droughtstressed corn grains varied from $80.6 \%$ to $85.6 \%$. Both studies showed lower ATTD of GE compared with the results in the current study, which may result from the different corn breeds or experimental conditions. For some other cereal grains commonly used in swine diets, the ATTD of GE was reported to be greater than that of corn grains. For example, the ATTD of GE in 8 low-tannin sorghum cultivars ranged from $87.15 \%$ to $89.89 \%$ [27], and the ATTD of GE in 12 wheat cultivar ranged from $88.14 \%$ to $90.31 \%$ [28].

Those energy values in corn grains obtained from the current experiment were lower than the values in NRC [11] (16.35 MJ DE/kg, 16.09 MJ ME/kg, and 12.71 MJ NE/kg) and Sauvant et al [16] (16.42 MJ DE/kg, 16.08 MJ ME/kg, and 12.84 MJ NE/kg). Nevertheless, current results agreed with values in Park et al [10] which reported average 16.01 MJ DE/kg and $15.73 \mathrm{MJ} \mathrm{ME} / \mathrm{kg}$ in 9 corn grain samples. In addition, different energy values in corn grains were reported in previous studies: $17.18 \mathrm{MJ} \mathrm{DE} / \mathrm{kg}$ [29], 16.96 MJ DE/kg [9], 15.40 MJ DE/kg [3], 14.38 MJ DE/kg [22]; 16.42 MJ ME/kg [9], 15.15 MJ ME/kg [3]; 13.05 MJ NE/kg [18], 12.22 MJ 
$\mathrm{NE} / \mathrm{kg}$ [3]. These differences in energy values among studies may be due to the various corn breeds and experimental conditions. Although differences in DE contents were observed among regions in this study, no difference was observed in $\mathrm{ME}$ or NE contents. This could be explained by the great deviation of the energy loss in urine. As a result, it was concluded that the available energy contents in corn grains are different among harvested regions and corn sources, which is consistent with previous studies $[7,9,10]$.

\section{Correlation coefficients and prediction equations}

It was reported that temperature and water stress had effects on the nutrient deposition in the cob formation in corn grains $[21,24]$. Different harvest environments could affect damaged to kernels [3]. It was also reported that physical characteristics were influenced by various meteorological conditions [23,24]. However, it is generally accepted that physical characteristics are not good parameters to predict the available energy contents in cereal grains fed to pigs compared with chemical characteristics $[9,15,27]$. It used to be widely believed that corn grown in northeastern China (Sources 3 to 4 in this study) had higher nutritional values compared with corn produced in southwestern China (Sources 5 to 20 in this study). The correlation analysis conducted in our study provided further proof that the geographical region is not directly related to the nutrient values of corn. We attribute the difference on energy content of corns from different regions to the chemical characteristics, animals, breeds and interactions between these factors [15].

As expected, EE was a positive predictor to estimate the energy contents in corn fed to growing pigs. Li et al [9] indicated that both EE and starch are reliable predictors in the estimation in DE and ME contents in corn. However, starch was not included in the prediction equations developed in the current study. Difficult to explain, similar results were also reported by Smith et al [29]. One possible explanation is that samples used herein was less variable on starch content compared with those in Li et al [9]. Moreover, GE was presented as a negative predictor for available energy estimations in the current equations, which was in consistent with equations reported by Pan et al [27], in which GE was also a negative predictor in estimating the energy contents in sorghum. Whereas both Li et al [9] and Zhao et al [28] reported a positive function of GE in predicting the available energy contents in corn and wheat, respectively. Above results indicated that GE was not as reliable as fiber components in energy contents prediction [15]. Previous studies suggested the superiority of $\mathrm{NDF}$ over ADF as a predictor in predicting DE and ME contents in corn fed to growing pigs $[3,9,15]$, which is consistent with the current study. Hemicellulose, an important fiber fraction, showed strong correlation with DE and ME contents in corn. In addition, better goodness-of-fit (greater $\mathrm{R}^{2}$ and smaller RMSE) was observed when NDF was replaced by hemicellulose and other predictors were fixed in the prediction equations for DE, ME, and ATTD of GE. This observation concurs with findings on wheat [28], in which xylan was an important predictor in predicting $\mathrm{DE}$ and $\mathrm{ME}$ contents. Similarly, it has been suggested that over $60 \%$ of variation in DE content in 9 corn products could be explained by xylose, which is a portion of hemicellulose [30]. In addition, hemicellulose was also a reliable predictor in NE prediction [15].

Prediction equations could substantially reduce the need for animal trials in determining the DE and ME values of the feedstuffs fed to pigs, thus saving money and time $[15,27]$. Sixteen corn samples (i.e. sources from 5 to 20) originated from Yunnan Province, China were used to generate prediction equations to predict the $\mathrm{DE}$ and $\mathrm{ME}$ contents in corn from Yunnan Province. Thus, corn originated from other areas (i.e. sources from 1 to 4 ) were not adopted to generate prediction equations.

\section{CONCLUSION}

This study indicated that the available energy contents in yellow dent corn originating from southwestern China were not correlated with the meteorological conditions such as temperature, humidity, or rainfall of the cropping environment. Chemical characteristics were more reliable factors compared with climatic origins or physical characteristics in predicting the DE and ME contents in yellow dent corn fed to growing pigs. This study also demonstrated the superiority of hemicellulose as a predictor in estimating the $\mathrm{DE}$ and ME values of corn grains.

\section{CONFLICT OF INTEREST}

We certify that there is no conflict of interest with any financial organization regarding the material discussed in the manuscript. Zhang S, Li X, Yang C are employees of Yunnan Xiernan Feed Limited Liability Company.

\section{ACKNOWLEDGMENTS}

This research was funded by the National Natural Science Foundation of China (31702121), the 111 Project (B16044) and Chinese Universities Scientific Fund (2019TC120). Appreciation is expressed to Yunnan Xiernan Feed Co., Ltd. (Yunnan, China) for assistance in corn sample collection.

\section{REFERENCES}

1. Stein HH, Lagos LV, Casas GA. Nutritional value of feed ingredients of plant origin fed to pigs. Anim Feed Sci Technol 2016;218:33-69. https://doi.org/10.1016/j.anifeedsci.2016. 
05.003

2. Food and Agriculture Organization of the United Nations (FAO). FAOSTAT [Internet]. 2018 [cited 2018 Nov 1]. Available from: http://faostat.fao.org/ home/E

3. Newman MA, Hurburgh CR, Patience JF. Defining the physical properties of corn grown under drought-stressed conditions and the associated energy and nutrient content for swine. J Anim Sci 2016;94:2843-50. https://doi.org/10.2527/ jas.2015-0158

4. Pilcher CM, Greco A, Hurburgh CR, Munkvold GP, Jones CK, Patience JF. Determining the energy digestibility of mold damaged corn selected for low mycotoxin content in finishing swine. J Anim Sci 2011;89(E-Suppl):755.

5. Patience JF, Myers AJ, Ensley S, Jacobs BM, Madson, D. Evaluation of two mycotoxin mitigation strategies in grow-finish swine diets containing corn dried distillers grains with solubles naturally contaminated with deoxynivalenol. J Anim Sci 2014; 92:620-6. https://doi.org/10.2527/jas.2013-6238

6. Beaulieu AD, Williams NH, Patience JF. Response to dietary digestible energy concentration in growing pigs fed cereal grain-based diets. J Anim Sci 2009;87:965-76. https:/doi. org/10.2527/jas.2007-0834

7. Sauber TE, Owens FN. Cereal grains and by-products for swine. In: Lewis AJ, Southern LL, editors. Swine nutrition, 2nd edition. Washington, DC, USA: CRC Press; 2001. Volume 2, p. 785-802.

8. Li Q, Shi M, Shi C, et al. Effect of variety and drying method on the nutritive value of corn for growing pigs. J Anim Sci Biotechnol 2014;5:18. https://doi.org/10.1186/2049-1891-5-18

9. Li Q, Zang J, Liu D, Piao XS, Lai CH, Li DF. Predicting corn digestible and metabolizable energy content from its chemical composition in growing pigs. J Anim Sci Biotechnol 2014; 5:11. https://doi.org/10.1186/2049-1891-5-11

10. Park CS, Son AR, Kil DY, Kim BG. Digestible and metabolizable energy in corn grains from different origins for growing pigs. Anim Sci J 2015;86:415-21. https://doi.org/10.1111/asj. 12315

11. NRC. Nutrient requirements of swine. 11th ed. Washington, DC, USA: National Academy Press; 2012.

12. AOAC. Official methods of analysis. 19th ed. Arlington, VA, USA; AOAC International; 2007.

13. Van Soest PJ, Robertson JB, Lewis BA. Methods for dietary fiber, neutral detergent fiber, and nonstarch polysaccharides in relation to animal nutrition. J Dairy Sci 1991;74:3583-97. https://doi.org/10.3168/jds.S0022-0302(91)78551-2

14. Adeola O. Digestion and balance techniques in pigs. In: Lewis J, Southern LL, editors. Swine nutrition, 2nd ed. Washington, DC, USA: CRC Press; 2001. p. 903-16.

15. Noblet J, Fortune H, Shi XS, Dubois S. Prediction of net energy value of feeds for growing pigs. J Anim Sci 1994;72:344-54. https://doi.org/10.2527/1994.722344x

16. Sauvant D, Perez JM, Tran G. Tables of composition and nutri- tional value of feed materials: pig, poultry, sheep, goats, rabbits, horses, fish. Wageningen, the Netherlands and INRA, Paris, France: Wageningen Academic Publishers; 2005.

17.CVB. Veevoedertabel (Table of nutritional value of feed ingredients). AD Lelystad, The Netherlands: Centraal Veevoederbureau; 2007.

18.Li Y, Lyu Z, Li Z, et al. Effects of feeding level and dietary supplementation with crystalline amino acids on digestible, metabolizable and net energy values of corn in growing pigs. Anim Feed Sci Technol 2018;240:197-205. https://doi.org/ 10.1016/j.anifeedsci.2018.04.009

19. Dwyer LM, Hayhoe HN, Culley JLB. Prediction of soil temperature from air temperature for estimating corn emergence. Can J Plant Sci 1990;70:619-28. https://doi.org/10.4141/cjps 90-078

20.Davidson VJ, Noble SD, Brown RB. Effects of drying air temperature and humidity on stress cracks and breakage of maize kernels. J Agric Eng Res 2000;77:303-8. https://doi.org/10. 1006/jaer.2000.0607

21. Çakir R. Effect of water stress at different development stages on vegetative and reproductive growth of corn. Field Crops Res 2004;89:1-16. https://doi.org/10.1016/j.fcr.2004.01.005

22. Bertol TM, Zanotto DL, Coldebella A, Ludke JV. Development and validation of equations to predict the metabolizable energy value of corn for pigs. J Anim Sci 2017;95:291-301. https://doi.org/10.2527/jas.2016.0832

23. Wang D, Zhang G. Meteorological factors-based corn grow simulation model research. J Maize Sci 2005;13:119-22.

24. Guo Z, Hou L, Li X, Qi L, Zhao M, Dong ZQ. The effects of chilling-resistant agents on corn growth, physiological and biochemical changes in low temperature stress. J Maize Sci 2008;16:82-5.

25.Liu D, Liu L, Li D, Wang F. Energy content and amino acid digestibility in hulled and dehulled corn and the performance of weanling pigs fed diets containing hulled or dehulled corn. Arch Anim Nutr 2013;67:301-13. https://doi.org/10.1080/ 1745039X.2013.818761

26. Kil DY, Park CS, Son AR, Ji SY, Kim BG. Digestibility of crude protein and amino acids in corn grains from different origins for pigs. Anim Feed Sci Technol 2014;196:68-75. https://doi. org/10.1016/j.anifeedsci.2014.06.008

27. Pan L, Li P, Ma XK, et al. Tannin is a key factor in the determination and prediction of energy content in sorghum grains fed to growing pigs. J Anim Sci 2016;94:2879-89. https://doi. org/10.2527/jas.2016-0457

28.Zhao JB, Tang SW, Zhou XJ, Dong WX, Zhang S, Huang CF. Determination of chemical composition, energy content, and amino acid digestibility in different wheat cultivars fed to growing pigs. J Anim Sci 2019;97:714-26. https://doi.org/ $10.1093 /$ jas/sky431

29. Smith B, Hassen A, Hinds M, et al. Predicting the digestible energy of corn determined with growing swine from nutrient 
composition and cross-species measurements. J Anim Sci 2015;93:1025-38. https://doi.org/10.2527/jas.2014-7807

30. Gutierrez NA, Serão NVL, Kerr BJ, Zijlstra RT, Patience JF. Relationships among dietary fiber components and the diges- tibility of energy, dietary fiber, and amino acids and energy content of nine corn coproducts fed to growing pigs. J Anim Sci 2014;92:4505-17. https://doi.org/10.2527/jas.2013-7265 